\title{
COASTAL COMMUNITY EMPOWERMENT STRATEGY AND THE ROLE OF LOCAL INFORMAL LEADERS
}

\author{
Purwowibowo, Budhy Santoso, Belgis Hayyinatun Nufus, Kris Hendrijanto \\ Lecturer in Social Welfare Department, Faculty of Social and Political Science, University of Jember \\ poerwowibowo@yahoo.co.id,dhysantos@yahoo.com,belgishayyinatunnufus@unej.ac.id, \\ kris.hendrijanto@gmail.com
}

\begin{abstract}
This article discusses the empowerment of coastal communities and the role of local informal leader in mangrove forest conservation. Mangrove forest has an ecological function of protecting the environment, including: resisting coastal abrasion, tsunamis, and breeding grounds for marine biota. Socio-economically, mangrove forest provides the beauty and comfort of the environment and is as learning facilities, so that they can be packaged as a destination for tourism. The condition of mangrove forest has been damaged but there have not been many results of conservation efforts that have been made. The conservation program is top-down and does not involve local community participation. In order to realize community participation in mangrove forest conservation an active and creative role is needed from informal leaders. This study uses a qualitative approach and is carried out in two districts, namely Jember and Banyuwangi Regencies. The result shows that local informal leaders have a strategic position, unique, respected, able to be role models and drivers of community activities so that coastal communities can jointly carry out mangrove forest conservation activities.
\end{abstract}

Keywords: local informal leaders, community empowerment, participation, conservation, mangrove forests.

\section{Introduction}

Mangrove forest is a sustainable natural resource because it can be renewed, and is an ecological asset that can sustain the lives of coastal communities (Sachs, J.D. et al., 2001). Coastal communities continue to grow, suppress the conditions and the sustainability of mangrove forests. Coastal areas have suffered damage from year to year, especially mangrove forests about 1,81 ha (KLH, 2018), so that many coastal conditions are not overgrown with mangrove trees. Many locations of mangrove forests have been damaged so that they have a negative impact on coastal communities, such as loss of coastal protection from wind and tsunamis, sea water intrusion that causes groundwater to experience pollution, coastal abrasion, and the threat of sustainability of fishponds and sea.

Mangrove forest conservation activities are part of community empowerment efforts (Purwowibowo, 2017). So far, efforts to reforest mangroves are top-down so they failed because there is no community participation. The conservation program offered in community empowerment is participatory (Badola, et al., 2012). A model that places the active participation of the community becomes important in every process. As 
empowerment based on coastal communities, it is necessary to have local informal leaders (Purwowibowo, 2016), who have high commitment and are able to mobilize community participation in mangrove forest conservation for the welfare of the entire community.

The position of informal leader in coastal communities is very important because they are in direct contact with the lower layers and their leadership status is obtained through social processes from below so that they have a high level of legitimacy. Informal leader also always comes in direct contact with the real problems faced by the community, because they are also part of the community. With its existence, informal leader will be the main node to communicate and bring together interests and messages from the public and the State or the government. Another function is to become a facilitator in resolving conflicting interests in the community. In fact, according to Santoso (2017) the existence of informal leader is able to fill in the empty space that is able to bring together the top-down and bottom-up development paradigms that have been considered as incapable of being synchronized.

\section{Research Method}

This study uses a qualitative approach which is presented descriptively. The selected locations are in two districts, namely Banyuwangi and Jember. In Banyuwangi Regency, include; (1) Community area of Bedul Mangrove Ecotourism, Gebang Kandel Sumberasri Village, Purwoharjo Subdistrict, (2) Community area of Kili-Kili Mangrove Forest, Tegalpare Hamlet, Wringinputih Village, Muncar Subdistrict, and (3) Community area around Kawang mangrove forest, Kawang Hamlet, Wringin Putih Village, Muncar District. Whereas those in Jember Regency include; (1) Communities around Getem Beach, Kalimalang, Mojomulyo, Puger Subdistrict, (2) Rowo Gabus Forest communities in Ungkalan Hamlet, Sabrang Village, Ambulu Subdistrict, and (3) Payangan Beach community, Watu Ulo Hamlet, Sumber Rejo Village, Ambulu Subdistrict.

Data collection uses participant observation, in-depth interviews and documentation. The primary informants were community leaders who initiated community empowerment efforts in realizing mangrove forests, as well as other informal figures who had direct and indirect links to mangrove rehabilitation activities. While secondary informants include coastal communities who are domiciled in research locations, village heads and heads or administrators of institutions that have concern for mangrove conservation. Data were analyzed and concluded using Milles and Huberman's analysis 
model with the perspective of "human ecology" and "green social welfare" by testing the validity of the data using the source triangulation method.

\section{Findings And Discussion}

Empowerment of coastal communities with mangrove forest conservation through the role of local informal leader, theoretically can be interpreted as community-based community empowerment. The successful use of community assets cannot be separated from the role of one of the community assets, namely social capital in the form of trust, values and networks that are embedded in an institution (Putnam, 2000).

The function of social capital is as a catalyst that is able to optimize other capital in community assets. In the context of coastal communities in the conservation of mangrove forests, these community assets are in the form of physical environmental capital, namely mangrove forest. Human capital is in the form of local informal leader with education and skills and spiritual capital in the form of religious and social values. All of the capital is able to become an encouragement for the community to engage in planting mangroves and material capital in the form of program assistance from the government to procure mangrove seedlings.

Local informal leader by utilizing social capital built through the existence of coastal communities can be integrated with community assets resulting in social reproduction. This opens the opportunity to create a process of social change that leads to the empowerment of the community to overcome social problems in coastal communities. In fact, these social changes take place in the social field, namely the change in participation which has so far been very low has increased according to changing behavior and concern for environmental conditions, especially mangrove forests.

\section{a) Local Informal Leader}

Local informal leader in coastal areas is a leader who emerges from the community and the process of community empowerment is called indigenous leader. He is a leader whose origin is from the local community and does not come from other communities. According to Adi (1998), indigenous leader is local informal leader whose power is limited to the scope of small communities. Conservation of mangrove forest, its authority is related to the process of community empowerment, especially conservation activities. The process of becoming an indigenous leader requires a long time and is usually the initiator of community empowerment. 
Indigenous leader is also called grassroots leader. According to Foster (2008), such leader does not have formal positions in their communities, but is recognized by the community as their leader. Indigenous leader position here is generally only the leader of fishpond farmer groups who care about mangrove forest conservation. However, this leader has many vertical and horizontal social networks, both in the form of social networks commensurate and not commensurate. Kusnadi (2006) and Taylor (2008), explain that commensurate social network is a social relationship that has the position of leader and who he leads there is no difference in status. Together they are members of the fishpond farmer groups. Whereas social networks are not commensurate with those related to the relationship between informal leaders and other higher leaders, such as village heads, heads of social organizations, and government leaders.

Kilduff and Tsai (2003), explained that grassroots leader is based on horizontal and vertical social networks called micro-networks and macronetworks. Micro social networks point to ties between community members and communities and their leaders, while the macro social network is a social relationship with various stakeholders who provide support for the rehabilitation of mangrove forests.

Informal grassroots leader is also related to the existence of local institutions (Winarno and Choesin, 2001). This mangrove rehabilitation activity involved many pond farmers and fishermen then formed a local organization, namely mangrove farmer groups. The existence of the next group was followed by the election of group leaders and other administrators. It was the chairperson of the pond farmers group that was the beginning of the emergence of informal grassroots leaders. Thus, the existence of local informal leaders is purely from community initiatives, so the group is also called a grassroots group. Grassroots groups are local institutions that are formed and organized informally and are based on community members' agreements.

Grassroots leader, in the empowerment of coastal communities is related to the knowledge and experience possessed related to mangrove conservation activities. This is different from the boat leader or boat captain (Kusnadi, 2006). The process is based on the principle of 'sea captivity' or boat captain based on certain abilities to reach the top of the social pyramid based on experience, abilities, and achievements in stages, starting from the bottom of the stairs to the boat captain. Indigenous coastal community leader or leader in community empowerment has not been traversed in stages and is based on knowledge and experience related to the rehabilitation of mangrove forests. As a grassroots leader used in community empowerment through mangrove forest 
conservation activities, this leadership turned out to be due to having a 'unique' and 'strategic' position, which is a position that embodies ease in promoting the importance of mangrove forest conservation efforts.

\section{b) Local Informal Leader and Community Empowerment}

Grassroots leader in community empowerment has a key role and at the local (coastal) community level and become 'spirits' or 'energies' from the activities of coastal communities. In addition, Foster (2008), local informal leader as agents of social change and is able to become initiators in finding new alternatives in restoring damage to mangrove forests. In fact, community empowerment can produce 'social products' (Adi, 1998), in this case in the form of mangrove forests.

Informal leader in community empowerment can build community social capital (Sulasmi, 2008; Gittel and Vidal, 1998). The social capital is related to socio-cultural values and environmental values, beliefs and social networks. Social capital can be in the form of community members' togetherness (Zeuli and Radel. 2004) and to build togetherness in coastal communities is done by forming groups through local institutions. Togetherness is actually a tangible form of active participation and mutual cooperation in the community in the conservation of mangrove forests. Togetherness in the form of mutual cooperation is an important social capital in the movement to plant mangroves. In fact, togetherness can be the key to the success of creating a mangrove forest, because such extensive activities without community support will not be realized.

Building social capital related also to local socio-cultural elements and natural conditions of coastal communities. Togetherness is a community's social capital that can be used as a 'spirit' and a vision of the community and used as a spirit to achieve community goals. As Putnam (1993) and Schneider (2006) stated, community social capital consists of three elements, namely norms or values (norms or values), trust (trust), and network (network). Community empowerment through mangrove conservation activities is through building community social capital related to socio-cultural conditions.

Informal leader builds social capital by revitalizing social cultural and environmental values. The results of this revitalization of socio-cultural and environmental values are used as a vision or reference in mangrove forest conservation and spirit or positive energy for all members of coastal communities. Revitalizing social capital will help clarify the vision and mission of the community, so that it can be used as a medium to make people aware of the problem of mangrove forest destruction. Thus, informal leader in building 
community social capital indirectly aimed at managing community assets used to improve the quality of life of the community. According to Delgado (2000), social capital is a catalyst for community assets in the form of environmental capital to be used as a 'source system' for solving community problems. Community empowerment through mangrove forest conservation has succeeded in restoring natural resources as environmental capital into sustainable community assets for the present and for the benefit of future generations.

By using social capital, togetherness in the community, local leader has succeeded in revitalizing the ideal values that society wants to become a shared value so that it functions as the spiritual capital of coastal communities. The spiritual capital in the form of spirit is formulated into the following jargon: 'the mangrove forest grows in a shady village '. The expression is a form of revitalization of socio-cultural and environmental values and is always held firmly by all members of the coastal community. Accompanied by network strengthening, trust and other social values as elements of social capital that exist between them, such spiritual capital is always communicated to community members. In subsequent developments, then came the development of value as a new spirit which became spiritual capital in the local community. The value of other social capital is the result of the revitalization of sociocultural and environmental values such as: 'fertile ponds are lived by prosperous communities and arid ponds are lived by inflamed coastal coastal communities'. A revitalization of socio-cultural values related to environmental values in the management of community assets to achieve the desired conditions with the community, namely the pond environment and fertile coastal environment.

Growth and fertilization of spiritual capital is also done by revitalizing religious values and environmental values. These values are revitalized by growing them into a vision of the community so that they can influence the community in responding to the damage to the coastal mangrove forests. Expressions such as: 'mangrove forests pray for their growers and preserver'. If the mangrove tree is hit by the wind, it will always shake. The swaying of mangrove trees as humans prayed shook his body. Mangrove growers are always prayed for by mangrove stems by swaying so that their better lives are often echoed and have become the spirit and understanding of the community in the conservation and conservation of these plants.

The relationship of coastal communities with God, as the creator of the universe, is an important spiritual capital in realizing mangrove forests, so it must manifest itself as part of the value in social capital. This relationship 
becomes a manifestation of the relationship between humans and God and their environment (Kusnadi, 2006). The form of planting mangrove is not only interpreted the relationship between humans and the environment, but also a form of relationship with God the Creator of Nature as a realization in carrying out the mandate of life. The results of work with the community in the form of mangrove forests are interpreted as good deeds to the environment and God. Thus, the environment in the form of mangrove forests then pray that humans who plant it will be rewarded for the good they do from God the Almighty.

In addition to revitalizing socio-cultural and environmental values, building social capital is building and strengthening trust. Trust is one of the social capital associated with social relations between members of coastal communities. In the process of community empowerment strong and high trust is needed. This is related to the difficulty of planting mangrove trees and requires the trust of community members to look after each other, help and maintain them. According to Putnam (1993) and Schneider (2006), trust is needed in building communities because there is a stigma about the difficulty of planting mangroves so that failure can affect people who are still convinced that the plants are difficult to plant and only God revives. To change this stigma, it needs to be strengthened by the belief that the plants can be planted by humans as long as the community is able to create good cooperation so that they have a shared commitment to look after each other, help and nurture it. The success of changing the negative stigma of society to be positive requires hard work from informal leader so that they can change it to become positive energy.

The process of building trust is done through joint activities in groups because in groups there is a process of uniting understanding, values, learning together and learning while working. With this learning process community members gain knowledge and experience from togetherness and mutual commitment in planting mangrove trees. Groups can be a medium for building trust and togetherness (Zeuli and Radel, 2004). With such togetherness, trust is then established between group members and other groups. Then the trust of community members can also grow and develop from exemplary and real examples from their informal leaders. This stage is at the same time a learning process for the community to interact between value and trust, that the realization of the value will be optimal if it is based on trust which is the basis for cooperation between them.

Local informal leader in community empowerment through the activities of mangrove forest conservation by utilizing social capital also touches on elements of strengthening social networks. Strengthened networks can take the 
form of horizontal or vertical social networks. Social networking (networking), is an element of social capital that greatly supports the success of the community in realizing mangrove forests. This form of social network can take the form of micro or macro. Micro social networks are networks that connect interests among members of the coastal community, while macro networks are networks that connect all members of the community with the wider community.

Conservation of mangrove forests through community empowerment is also supported by local social networks. According to Traynor and Andor (2005), local social networks can accelerate the productive economic activities of coastal communities with the wider community. Local products from productive economic activities of the community can be distributed to other communities in a more remote place. With social networks, there is an acceleration in the improvement of the economy in coastal communities so that it can improve the quality of life and welfare of the people.

\section{c) Local Informal Leader and Mangrove Forest Rehabilitation}

In the process of empowering coastal communities for mangrove forest conservation, it shows that informal leade plays a very important role in organizing communities in designing group member activities and community activities. Homan (2004) explains that the role of community organizers is an important task in achieving goals, which is responsible for the realization of mangrove forests. Organizing activities cover all processes to help the community in planning and carrying out all of its activities.

One of the functions of local informal leader role is to communicate the vision of the community and develop a framework so that conservation activities of mangrove forests run more effectively and efficiently. Netting \& Mary (2003), explains that the role of local informal leaders in organizing community members is more effective and efficient through local institutions. Similarly Rubin and Rubin (2001), explain that community members are easily organized through local institutions rather than working independently. Creating ties in local institutions so that they can be stronger is one method in social welfare interventions, namely community organizations and is a community intervention method (Barker, 1995).

Increased participation of community members is also the success of local informal leader in carrying out community empowerment processes. This success is realized by continuous efforts, regarding efforts to capture the understanding and awareness of community members about the importance of mangrove forests for the lives of coastal communities. Erftemeijer and Bualuang 
(1998) explained that the rehabilitation of top-down mangrove forests in coastal areas would be successful if accompanied by active participation by community members. The involvement of coastal communities is an important factor in the rehabilitation of mangrove forests because it is realized that in mangrove forests there are many other natural resources that can be used for the benefit of the entire community, especially for pond farmers.

Building and growing community members' participation takes a long time because mangrove forest conservation initially gets resistance from coastal communities. Community members' rejection of community empowerment in the activities of mangrove forest conservation that had occurred was caused by the failure of planting by local informal leader at that time. As stakeholders, the failure is learned not to repeat itself, accompanied by efforts to create and grow trust in the value that mangroves will provide benefits to the community. Finally, little by little the planting of mangroves appears to produce results, so that they can give a concrete example of what has been done and it becomes the best teacher for coastal communities that gives rise to developing empathy and active participation.

Local informal leader in mangrove forest conservation is also called volunteers and in social welfare sciences is called community workers, rural workers, or community developers (Ritter, 2009). As community volunteers in mangrove forest conservation, because the aim is to increase added value from community activities in managing their environment. The activity is a process of continuous social change, so it can also be referred to as 'social entrepreneurship' (Greenberg, 1999). Social entrepreneurship is not capitalizing on social capital for economic change, but utilizing business techniques to find solutions to social problems.

As a social entrepreneur, what is done is trying to create social change, so that independence can be created through opportunities that can be used to expand business opportunities for coastal community members. Opportunities can be in the fields of social, cultural, creative economy, and productive economics to overcome problems perceived by the community. The formation of farm and coastal farmer groups, savings and loan lottery, tactical funding, and the formation of women's groups is a manifestation of the impact of the success of social entrepreneurs. This is related to the search for solutions to the socio-economic problems of the community and is the result of the 'social reproduction' process and from community organizing related to mangrove forest conservation. Social reproduction is the process of re-creating social conditions using the basis of social conditions that have been produced before. Thus, social reproduction can be interpreted as a process to preserve or 
perpetuate the characteristics of certain social structures or traditions over a period of time. Adi (1998), explains that social products can take the form of ideas, practices, and real forms and conservation of mangrove forests is a manifestation of social reproduction of values that are understood by the benefits of the existence of mangrove forests for coastal communities.

\section{Conclusion}

Empowerment of coastal communities through mangrove forest conservation and the role of local informal leader have succeeded in realizing social reproduction. This means that empowerment that has resulted in mangrove forests not only produces physical capital but also is able to open opportunities for people in various fields of work so that the conditions of social welfare of coastal communities become more improved. Community assets in the form of mangrove forests and other assets related to coastal and marine areas are strongly influenced by the sustainability of mangrove forests. All aspects of building and revitalizing community-based social capital can be well implemented. The existence of community assets such as human capital, namely a community aware of the coastal environment is made aware of by local informal leader. Environmental social capital namely fertile mangrove forest and other social capital are important catalysts in people's lives. The socio-cultural values that are successfully used as a driver in achieving goals are trust and social networks. All of them can be utilized in the process of community empowerment in the form of social movements in the conservation of mangrove forests on the coast. This is inseparable from the role and existence of local informal leader who is able to utilize community assets by actively involving community participation. Finally, community empowerment and development can be successful so that it impacts on the sustainability of mangrove forests and enhances the welfare of the community, especially in the social and economic sectors.

\section{ACKNOWLEDGMENT}

Thank you to the Chancellor of the University of Jember who provided the opportunity and funding to the research team through research grants to the Community Empowerment and Development Reseach Group of the Social Welfare Department 2018 budget year. The Chair of the LP2M University of Jember who gave authority and assignment letters to the group research team this research, so that this research can be carried out and completed. To all informants who cannot be mentioned one by one and have provided 
information in data collection, in the regions of Jember and Banyuwangi Regencies, thank you for the hospitality and cooperation.

\section{REFERENCE}

Adi, I. R. (1998). Empowerment, Community Development and Community Intervention. Institute for Publishing the Faculty of Economics, University of Indonesia. Jakarta Indonesia.

Badola, R. et al. (2012) Attitudes of local communities towards conservation of mangrove forests: A case study from the east coast of India. Estuarine, Coastal and Shelf Science Volume 96, Pages 188-196. https://doi.org/10.1016/j.ecss.2011.11.016

Barker, R. L. (1995). The Social Work Dictionary. 3rd Edition. Washington, DC.: National Association of Social Worker.

Delgado, M. (2000). Community Social Work Practice in an Urban Context: The Potential of a Capacity-Enhancement Perspective. England: Oxford University Press.

Erftemeijer, P. L. A. and Bualuang, A. (1998) Participation of Local Communities in Mangrove Forest Rehabilitation in Pattani Bay, Thailand: Learning from Successes and Failures. In Strategies for Wise Use of Wetlands: Best Practices in Participatory Management. Proceeding of a Workshop held at the $2^{\text {th }}$ International Conference on Wetlands and Development (November 1998, Dakar, Senegal).

Foster, M. (2008). Informal Leadership in Community-Driven Development: Implications for Transformation. ProQuest Dissertations and Theses. The Humanities and Social Sciences Collection pg. n / a.

Gittell, R. and Vidal, A. (1998). Community Organizing. Building Social Capital as a Development Strategy. USA: Sage Publication, Inc.

Greenberg, S. (1999). Building a People-Driven Rural Development Strategy: Lesson from The RDI. In Cousin B. (Ed.) Book chapter: Conference paper. At the crossroads: land and agrarian reform in South Africa into the 21st century. Papers from a conference held at Alpha Training Centre, Broederstroom, Pretoria, South Africa: 26-28 July (1999

Homan, M. S. (2004). Promoting Community Change. Making It Happen in The Real World. Third Edition. Australia: Thomson. 
Ministry of Environment of the Republic of Indonesia (2018). Republika. co.id https://www.republika.co.id/berita/ekonomi/makro/18/01/10/p2bu1r 382-kementerian-lhk-sebut-181-juta-hektare-mangrove-rusak.

Kilduff, M. and Tsai, W. (2003). Social Network and Organization. London: Sage Publication.

Kusnadi (1997). Job Diversification among Fishermen. Prisma. No. 7 Tahun XXVI Juli - August.

(2006). The philosophy of empowering Coastal Communities. Bandung: Humaniora Utama Press.

Netting, F. E. \& Mary. (2003). Organization Practice. A Social Worker's Guide to Understanding Human Service. Boston, New York, San Francisco: AB-Press.

Purwowibowo and Gianawati, N. (2016). Local Wisdom in the Conservation of Mangrove Forests through Community Development. Environmental Law Development Journal. Vol. 1, No. 1.

Purwowibowo and Soni A. Nulhaqim (2017), Mangrove Forest Banggi Rembang Market, Rehabilitation, Community Development, and Informal Leaders. Pandiva Books. Jogyakarta.

Putnam, R. (1993). 'The Prosperous Community: Social Capital and Public Life'. The American Prospect (13) :35-42.

(2000). "Bowling Alone: The Collapse and revival of American Community". Journal of Polical Science and Politics. pp . 43.

Rubin, H. J. And Rubin, I. S. (2001). Community Organizing and Development. Third Edition. Boston USA: Allyn and Bacon.

Sachs, J. D. et al. (2001) Natural Resources and Economic Development: The course of natural resources. European Economic Review. Volume 45, Issues 4-6, May 2001, Pages 827-838. https://doi.org/10.1016/S00142921(01)00125-8.

Santoso, B. Learn from Informal Leader in East Java. Dissertation. Unpublish. (2017)

Schneider, J. A. (2006). Social Capital and Welfare Reform, Organizations, Congregations, and Communities. New York: Columbia University Press. 
Sulasmi, S. (2008). The Influence of Leadership Building the Spirit of Collaboration with Vision Togetherness as a Moderator Variable. Surabaya: Economic Magazine, Year XVIII. No.1 April p. 35 - 53

Taylor, J. (2008). Working With Communities in Health and Human Services. South Melbourne: Oxford University Press.

Traynor, W. J. And Andors, J. (2005). Network Organizing: A Strategy for Building Community Engagement. Working Paper of Strategy Development: Executive director and director of resource development at Lawrence Community Works.

Winarno, K. dan dan Ahmad Dwi Setyawan. (2006). "Cutcross Citanduy River, Simalakama Fruit Mangrove Ecosystem Conservation Segara Anakan", Jurnal Biodiversitas 4, no. 1 p. 63-72, http:/ / eprints.uns.ac.id/845/

Zeuli, K. and Radel, J. (2005). Cooperative as a Community Development Strategy: Linking Theory and Practice". Journal of Regional Analysis and Policy. Vol. 35. No. 1. 